\title{
Increasing ovulation rate and lambing rate in sheep by treatment with a steroid enzyme inhibitor*
}

\author{
R. Webb \\ A.F.R.C., Institute of Animal Physiology and Genetics Research, Dryden Laboratory, Roslin, \\ Midlothian, EH25 9PS, U.K.
}

\begin{abstract}
Summary. Treatment of ewes with a $3 \beta$-hydroxysteroid dehydrogenase (3$\beta$-HSD) inhibitor (Epostane) resulted in a significant increase in both ovulation rate and in the mean number of lambs per ewe lambing. The progestagen sponge plus $3 \beta$-HSD inhibitor treatment also caused a significant increase in oestrous cycle duration of approximately 1.5 days. Treatment of ewes with the $3 \beta$-HSD inhibitor caused a significant decrease in peripheral progesterone concentrations, which were reduced even further when $3 \beta$-HSD inhibitor treatment was given to ewes after insertion of a progestagen sponge. However, mean oestradiol concentrations were significantly higher in the two treatment groups, both at the end of the luteal phase and during the follicular phase of the oestrous cycle. These results demonstrate that ovulation rate and the production of lambs per ewe lambing can be significantly increased by $3 \beta-\mathrm{HSD}$ inhibitor treatment.
\end{abstract}

\section{Introduction}

In domestic animals, particularly sheep and cattle, the ability to control the number of eggs shed would lead to a significant improvement in reproductive efficiency. In sheep the exact mechanisms controlling ovulation rate are not known (see reviews by Webb \& Gauld, 1985a, b; Bindon \& Piper, 1984), although part of the control appears to involve a dynamic balance between the stimulatory effects of gonadotrophins upon the ovary and inhibition of gonadotrophin release by the feedback action of hormones from the ovary upon the hypothalamus-pituitary gland (Land \& Carr, 1979). Differences in peripheral gonadotrophin concentrations have been found between breeds (see review by Bindon \& Piper, 1984) and it has been demonstrated that follicle growth beyond $2.0 \mathrm{~mm}$ in diameter in ewes is dependent on adequate secretion of both LH and FSH by the pituitary gland (Dufour et al., 1979; McNeilly et al., 1986).

It is therefore suggested that perturbation of the hypothalamus-pituitary gland-ovarian feedback system should have a significant effect on ovulation rate and follicular growth. This hypothesis is supported by previous reports that both active and passive immunization against ovarian steroids can lead to a significant increase in ovulation rate (see reviews by Scaramuzzi \& Hoskinson, 1984; Webb et al., 1984) together with marked changes in the pattern of gonadotrophin release (Martensz et al., 1979; Pathiraja et al., 1984). Conversely, a physiological increase in the peripheral concentrations of oestradiol, by using subcutaneous implants, decreases ovulation rate (Webb \& Gauld, 1985a) and also causes a reduction in the number of 'active' follicles (Webb \& Gauld, 1986).

Treatment of animals with various competitive inhibitors of the enzyme, $3 \beta$-hydroxysteroid dehydrogenase ( $3 \beta$-HSD), has previously been shown to reduce steroid hormone production in different reproductive tissues of different species, including the rhesus monkey (Schane et al., 1979), women (Pattison et al., 1984a, b), sheep (Taylor et al., 1982; Jenkin et al., 1984) and rats (Snyder et

*Presented as the Arthur Walpole Memorial Lecture to the Society for the Study of Fertility, University of Aberdeen, 1985. 
al., 1984). For example, treatment in sheep during the luteal phase of the oestrous cycle (Ashworth et al., 1987) and also during late pregnancy (Ledger et al., 1985) causes a significant reduction in progesterone concentrations. The aim of these studies was to investigate whether treatment with a $3 \beta$-HSD inhibitor would increase ovulation rate by reducing ovarian steroid production.

\section{Materials and Methods}

\section{Animals}

Two experiments were carried out during the normal breeding season (November and December) in 44 Welsh Mountain ewes. For the period of the two studies the ewes were housed in sheds at Blythbank Farm, West Linton, Borders Region, and fed on hay and concentrates as dictated by normal husbandry practice.

\section{Experimental designs}

Experiment 1. There were 3 experimental groups: Group 1, treated with vehicle only $(\mathrm{N}=15$; mean \pm s.e.m. bodyweight $=42.5 \pm 1.0 \mathrm{~kg})$; Group 2 , treated with the $3 \beta$-HSD inhibitor only $(\mathrm{N}=15$, mean \pm s.e.m. bodyweight $=$ $40.8 \pm 1 \cdot 1 \mathrm{~kg})$; Group 3 , treated with $3 \beta-\mathrm{HSD}$ inhibitor together with a progestagen sponge $(\mathrm{N}=14$, mean \pm s.e.m. bodyweight $=42 \cdot 4 \pm 1 \cdot 1 \mathrm{~kg}$ ).

The oestrous cycles of all ewes had previously been synchronized using a 12-day intravaginal treatment with progestagen sponges containing $60 \mathrm{mg}$ medroxyprogesterone acetate (Veramix: Upjohn Ltd, Crawley, Sussex, U.K.). Blood samples were collected from all ewes by jugular venepuncture at 12 -h intervals from Day 8 (oestrus $=$ Day 0 ) of the treatment cycle until oestrus. Serum was stored at $-20^{\circ} \mathrm{C}$ until assayed. After blood sample collection, ewes were injected subcutaneously twice daily, either with vehicle $(2 \mathrm{ml}$ ethanol/ethyl oleate, Group 1), or 33-HSD inhibitor $(50 \mathrm{mg} /$ injection; Groups 2 and 3) from Day 10 to the morning of Day 15 of the treatment cycle. A previous dose

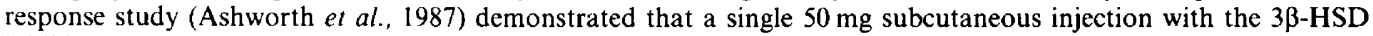
inhibitor (Epostane; Sterling-Winthrop, Guildford, Surrey, U.K.) could reduce circulating progesterone concentrations by about $70 \%$ over a 12 -h period. To ensure that the low progesterone concentrations did not allow the premature occurrence of preovulatory LH surges, progestagen sponges were positioned in the vagina of Group 3 ewes from Day 8 to Day 14 of the treatment cycle. Oestrus was checked by running the ewes with raddled vasectomized rams and the ovaries of all ewes were observed at mid-ventral laparoscopy between Days 3 and 7 of the following oestrous cycle to ascertain ovulation rate and ovarian morphological structures.

Experiment 2. Ewes were reallocated into two groups: Group $1(\mathrm{~N}=22)$ receiving vehicle (in Exp. 1 the animals were in the control group plus 7 ewes from $3 \beta$-HSD inhibitor only group; mean ovuiation rate $=1.50 \pm 0.13$ ) and Group $2(N=22)$ receiving $3 \beta$-HSD inhibitor (in Exp. 1 the animals were in the $3 \beta$-HSD inhibitor plus sponge group plus 8 ewes from the $3 \beta$-HSD inhibitor only group; mean ovulation rate $=1.77 \pm 0.13$ ). The animals were not randomized before reallocation because it has already been demonstrated (Ashworth et al., 1987) that the effect of the $3 \beta$-HSD inhibitor is of short duration, about $12 \mathrm{~h}$ compared to a 16-day oestrous cycle, and therefore the chances of carryover were considered to be minimal. Ewes in Groups 1 and 2 were treated twice daily between Days 10 and 15 as described for Exp. 1. At the oestrus after treatment ewes were hand-mated with intact rams. All ewes underwent mid-ventral laparoscopy between Days 4 and 9 of the following cycle.

\section{Hormone assays}

Oestradiol. Concentrations of oestradiol in peripheral plasma were determined in duplicate by radioimmunoassay incorporating an affinity chromatography extraction procedure as described previously (Webb et al., 1985). The assay results were computed by the A.B.R.O. Radioimmunoassay Program package based on the method of Rodbard \&

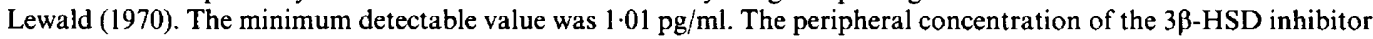
(W. E. Jones, Sterling-Winthrop, personal communication) was $<40 \mathrm{ng} / \mathrm{ml}$ and the cross-reaction in the assay at this concentration was undetectable. Moreover, negligible cross-reaction $(<0.001 \%)$ was observed at $50 \%$ displacement of the tracer when tested in vitro. There was no difference in peripheral oestradiol concentrations between control ewes and those treated with the progestagen sponges, indicating a lack of cross-reactivity with the circulating medroxyprogesterone acetate. The inter-assay ( $n=10$ assays) coefficients of variation using three standard quality control samples with mean oestradiol concentrations of $7.9 \pm 0.4,14.2 \pm 0.5$ and $25.9 \pm 0.8 \mathrm{pg} / \mathrm{ml}$ were $14.8,11.3$ and $9.5 \%$ respectively, and the intra-assay coefficient of variation was $10 \cdot 5 \%$.

Progesterone. Concentration of progesterone in peripheral plasma was determined in duplicate using the radioimmunoassay described by Corrie et al. (1981) and modified by Ashworth (1985). The minimum detectable value was

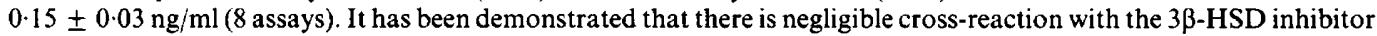
as $<0.001 \%$ cross-reaction was observed at $50 \%$ displacement of the progesterone tracer in vitro and the injection of $50 \mathrm{mg}$ inhibitor into 5 ovariectomized ewes daily, for 3 days, had no effect on the basal progesterone concentrations (Ashworth et al., 1987). Likewise, medroxyprogesterone acetate also had negligible cross-reaction with the assay as 
progesterone concentrations actually decreased after progestagen sponge treatment. The interassay coefficients of variation ( $n=8$ assays) in 3 quality control samples with mean progesterone concentrations of $2 \cdot 10 \pm 0.06$, $3.01 \pm 0.16$ and $7.7 \pm 0.33 \mathrm{ng} / \mathrm{ml}$ was $7.8,15.2$ and $12.2 \%$ respectively and the intra-assay coefficient of variation was $8 \cdot 8 \%$.

\section{Statistical analyses}

Unless otherwise indicated, significant differences between groups were analysed using analysis of variance and incorporating Scheffe's multiple comparison test (Scheffe, 1959). The hormone data were transformed to natural logarithms before analysis.

\section{Results}

\section{Ovulation rate, ovarian morphology and oestrous cycle duration}

Experiment 1. Treatment with the $3 \beta$-HSD inhibitor alone caused a significant increase $(P<0.0$ I) in ovulation rate (Table 1$)$. The increase in ovulation rate in the ewes treated with the progestagen sponges together with the $3 \beta-H S D$ inhibitor was less marked. These ewes did, however, have a significant increase $(P<0.01)$ in oestrous cycle duration of about 1.5 days (Table 1$)$, so that the interval between the end of treatment and ovulation was greater. There was no significant difference in oestrous cycle length between the control ewes and the ewes receiving the $3 \beta-\mathrm{HSD}$ inhibitor only (Table 1). The increase in ovulation rate after inhibitor alone was due to more ewes showing double and triple ovulations, whereas in both the control group and the group treated with the $3 \beta$-HSD inhibitor plus the progestagen sponge none of the ewes had more than 2 ovulations.

Experiment 2. As in Exp. 1 treatment again induced an increase in ovulation rate (Table 2), which reached significance $(P<0.05)$ when omitting the 2 ewes that did not ovulate. In this study 8 other animals also failed to exhibit oestrus. Again the increase in ovulation rate was due to more ewes showing double and triple ovulations. The increase in ovulation rate was also accompanied by changes in gross ovarian morphology, which was more pronounced in Exp. 2 compared with Exp. 1 (see Tables $1 \& 2$ ). Large follicles (estimated at 6-8 $\mathrm{mm}$ in diameter) were present at the time of laparoscopy, together with ovarian follicular cysts. As in Exp. 1, there was no difference in oestrous cycle length between the two groups.

Table 1. Effect of treatment on ovulation rate, oestrous cycle duration and gross ovarian morphology in sheep

\begin{tabular}{|c|c|c|c|}
\hline & Control & $\begin{array}{c}\text { 3/-HSD } \\
\text { inhibitor } \\
\text { only }\end{array}$ & $\begin{array}{c}3 \beta-H S D \\
\text { inhibitor plus } \\
\text { progestagen sponge }\end{array}$ \\
\hline No. of ewes & 15 & 15 & $13 \dagger$ \\
\hline Mean ovulation rate $( \pm$ s.e.m. $)$ & $1 \cdot 27 \pm 0 \cdot 12^{\mathrm{a}}$ & $2 \cdot 00 \pm 0 \cdot 17^{b}$ & $1 \cdot 62 \pm 0.14^{\mathrm{ab}}$ \\
\hline No. of corpora lutea $\{2$ & 4 & 9 & 8 \\
\hline $\mid 3$ & 0 & 3 & 0 \\
\hline No. of ewes with large follicles & 1 & 2 & 4 \\
\hline No. of ewes with cystic follicles & 0 & $2^{*}$ & 0 \\
\hline Duration of oestrous cycle (days) & $16 \cdot 80 \pm 0 \cdot 14^{x}$ & $16 \cdot 46 \pm 0 \cdot 17^{x}$ & $18 \cdot 15 \pm 0 \cdot 19^{y}$ \\
\hline $\begin{array}{l}\text { Range for the group (days) over which oestrus } \\
\text { was exhibited }\end{array}$ & $16-18$ & $15-17$ & $17-19$ \\
\hline
\end{tabular}

Values with different superscripts are significantly different $(P<0 \cdot 01)$.

†Data from Ewe 42 not included because of a 20 -day oestrous cycle, due to an extended luteal phase (see Fig. 2).

†Well vascularized, $6-8 \mathrm{~mm}$ in diameter, similar to preovulatory follicles.

*One ewe had 2 cystic follicles. 
Table 2. Effect of $3 \beta-H S D$ inhibitor on ovulation rate, oestrous cycle duration and gross ovarian morphology in sheep

\begin{tabular}{|c|c|c|}
\hline & $\begin{array}{l}\text { Vehicle } \\
\text { only }\end{array}$ & $\begin{array}{l}3 \beta \text {-HSD } \\
\text { inhibitor }\end{array}$ \\
\hline No. of ewes & 22 & 22 \\
\hline Mean ovulation rate $( \pm$ s.e.m.) & $1 \cdot 27 \pm 0 \cdot 10$ & $1.75 \pm 0 \cdot 16^{*}$ \\
\hline & 0 & 2 \\
\hline \multirow{3}{*}{ Distribution of corpora lutea } & 16 & 8 \\
\hline & 6 & 9 \\
\hline & 0 & 3 \\
\hline No. of ewes with large follicles & 0 & 3 \\
\hline No. of ewes with cystic follicles & 0 & $9 \dagger$ \\
\hline Duration of oestrous cycle (days) & $16.86 \pm 0.14$ & $17.00 \pm 0.18 \ddagger$ \\
\hline
\end{tabular}

*Significantly different from controls $(P<0.05$; Student's $t$ test). Two ewes did not ovulate, but if these animals are included the mean ovulation rate $=$ $1 \cdot 59 \pm 0 \cdot 18$.

†One ewe had 2 cystic follicles and one ewe had 4 cystic follicies.

$\ddagger 8$ ewes failed to exhibit oestrus.

Table 3. Effect of treatment on the number and distribution of lambs per ewe

\begin{tabular}{|c|c|c|}
\hline & $\begin{array}{l}\text { Vehicle } \\
\text { only }\end{array}$ & $\begin{array}{l}3 \beta \text {-HSD } \\
\text { inhibitor }\end{array}$ \\
\hline $\begin{array}{l}\text { No. of ewes lambing }{ }^{\dagger} \\
\text { Mean no. of lambs per ewe lambing } \\
( \pm \text { s.e.m.) }\end{array}$ & $1.19 \pm 0.09$ & $\begin{array}{c}11 \\
1 \cdot 55 \pm 0 \cdot 16^{*}\end{array}$ \\
\hline Distribution of lambs $\left\{\begin{array}{l}1 \\
2\end{array}\right.$ & $\begin{array}{r}17 \\
4\end{array}$ & $\begin{array}{l}5 \\
6 \ddagger\end{array}$ \\
\hline
\end{tabular}

*Significantly different from vehicle only group $(P<0 \cdot 05$, Student's $t$ test $)$.

tIncludes only those ewes that were pregnant to the mating after the treatment cycle.

$\ddagger$ Two lambs from the treatment group, both from sets of twins, were born dead.

\section{Number of lambs}

Experiment 2. In those ewes that became pregnant to the mating directly after treatment there was a significant increase $(P<0.05)$ in the mean number of lambs per ewe lambing (Table 3$)$. This was due to a higher proportion of ewes having twin lambs, with no ewes giving birth to triplets.

\section{Peripheral progesterone and oestradiol concentrations}

Experiment 1 . Treatment with the $3 \beta$-HSD inhibitor caused a significant reduction $(P<0.01)$ in the peripheral concentrations of progesterone (Figs la \& $1 \mathrm{~b}$ ). In addition, the progestagen sponge treatment significantly reduced progesterone concentrations further $(P<0.01, t$ test $)$, even before $3 \beta$-HSD inhibitor treatment $(P<0.05, t$ test $)$. Three of the animals showed a marked transient increase in progesterone concentration after the last injection with inhibitor, with progesterone concentration reaching luteal-phase levels. This was particularly evident in Ewe 42 (Fig. 2) in which luteal-phase progesterone concentrations were maintained for at least 2 days after the cessation of $3 \beta$-HSD treatment. This animal also had an oestrous cycle length of 20 days, 1 day longer than any of the other ewes in the treatment group and therefore has been dealt with separately. Oestradiol concentration in this ewe also increased significantly during the follicular phase of the cycle (Fig. 2). 


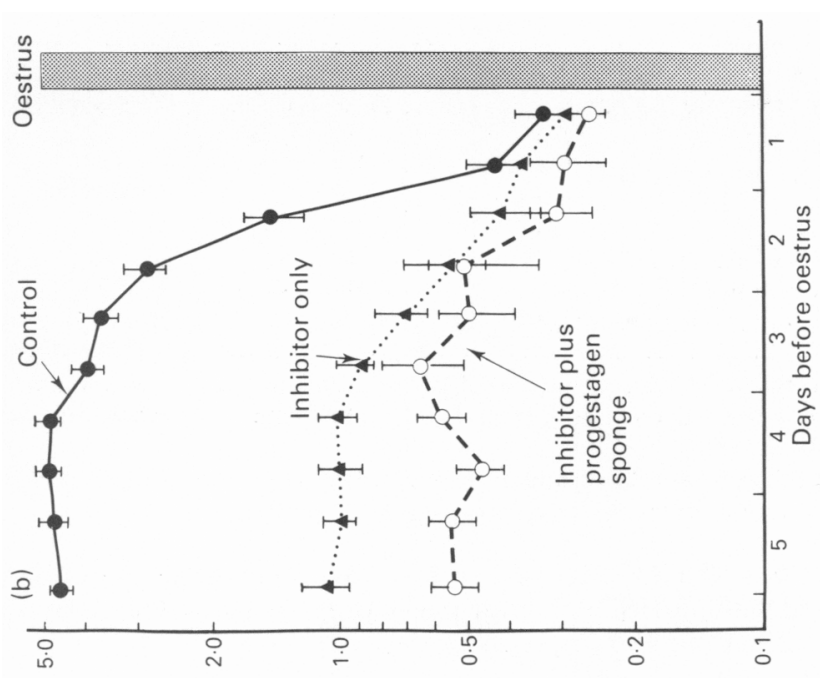

$\stackrel{\Xi}{\Xi}$

일

.

要

동

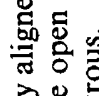

䨔至索

के

总

윤.

ป气

咅.

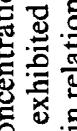

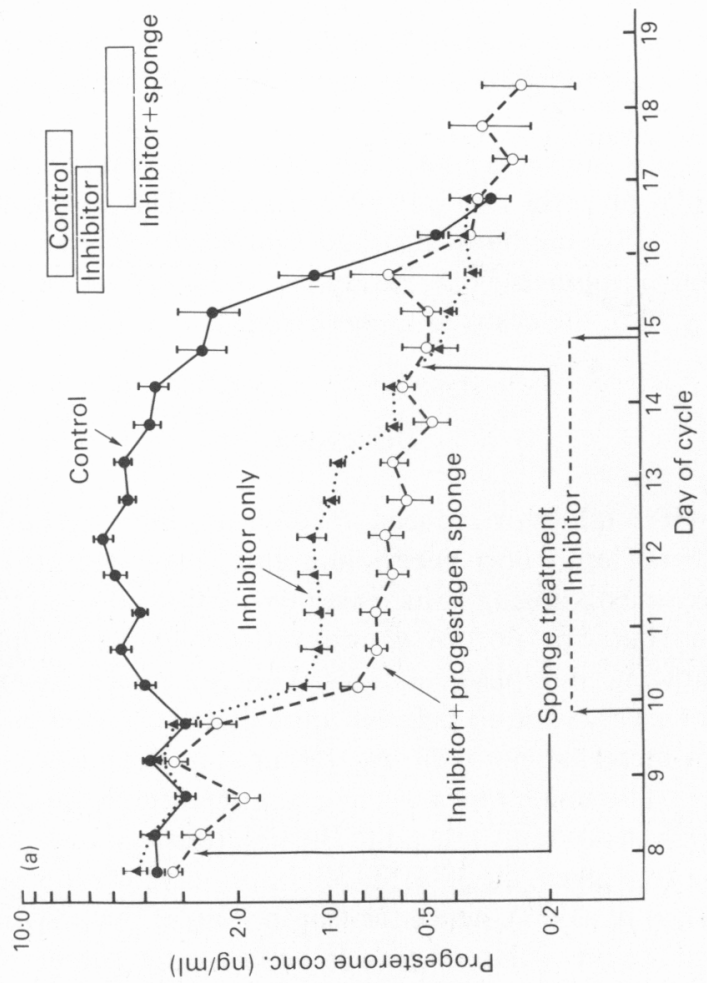

ن

త 3 .

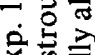

视

品.

들을

政

동호옹

营刍。

옹

8

:

to

远

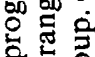

언

E

站声

+1 远

苛吉

$\sum$

:

옹

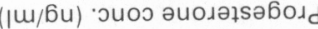




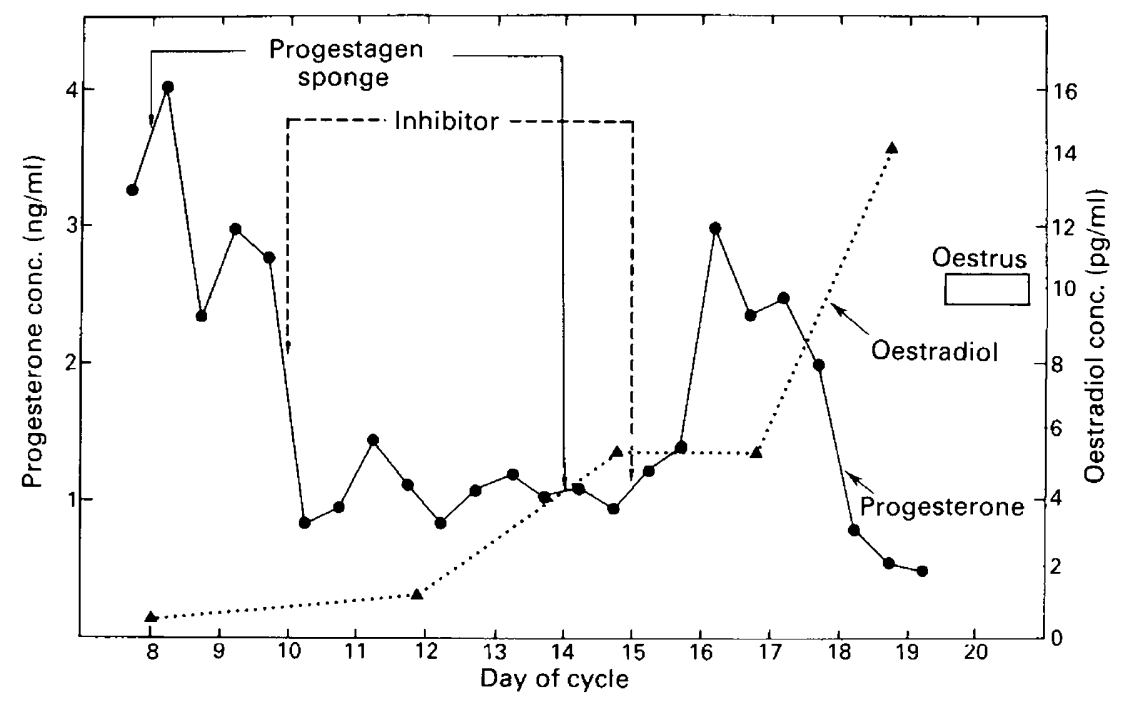

Fig. 2. Progesterone ( -0 ) and oestradiol ( $\boldsymbol{\Delta}--\boldsymbol{\Delta}$ ) concentrations during the oestrous cycle of Ewe 42 treated with $3 \beta$-HSD inhibitor plus a progestagen sponge. The results for this animal are not included in Table 1 or Figs 1 and 3.

There appeared to be no increase in the length of the follicular phase between the groups (Fig. 1b), although this becomes difficult to assess due to the lowering of the progesterone concentrations by the treatment.

As expected, all 3 groups showed a significant increase $(P<0.01)$ in mean oestradiol concentration during the follicular phase of the oestrous cycle (Figs $3 \mathrm{a} \& 3 \mathrm{~b}$ ). Unexpectedly, however, the ewes treated with the $3 \beta$-HSD inhibitor also had significantly higher oestradiol concentrations $(P<0.01)$ than did control animals both during the follicular phase of the oestrous cycle and during treatment on Day 14 of the oestrous cycle (Fig. 3a).

\section{Discussion}

Treatment with the $3 \beta-H S D$ inhibitor induced a significant increase both in the number of eggs ovulated and in the number of lambs born per ewe lambing. This appears to be the first demonstration of an enzyme inhibitor treatment causing an increase in ovulation rate. The improvement in ovulation rate was due to an increase in the proportion of ewes showing twin and triple ovulations rather than to an occasional ewe showing multiple ovulations. This is a major advantage as the response to gonadotrophin treatment is very variable between animals and can lead to excessive superovulation (see Hunter, 1980), with increased prenatal loss (Hanrahan \& Quirke, 1985) and reduced lamb birthweight (Black, 1983). The smaller increase in ovulation rate in the ewes treated with inhibitor plus progestagen sponges was probably related to the significant increase in oestrous cycle length in this group of ewes. At the dose given, the $3 \beta$-HSD inhibitor only lowers progesterone concentrations for about $12 \mathrm{~h}$ (Ashworth et al., 1987), hence the lengthening of the oestrous cycle and the interval from final treatment until the preovulatory gonadotrophin surge presumably reduced the effect of the inhibitor.

The increase in ovulation rate was also accompanied by changes in gross ovarian morphology (Tables $1 \& 2$ ), as indicated by the presence of large follicles and cystic follicles at laparoscopy, 3-9 days after oestrus. The presence of cystic follicles, especially in Exp. 2 suggests that the treatment interfered with the hormonal feedback equilibrium between the hypothalamus-pituitary gland and 


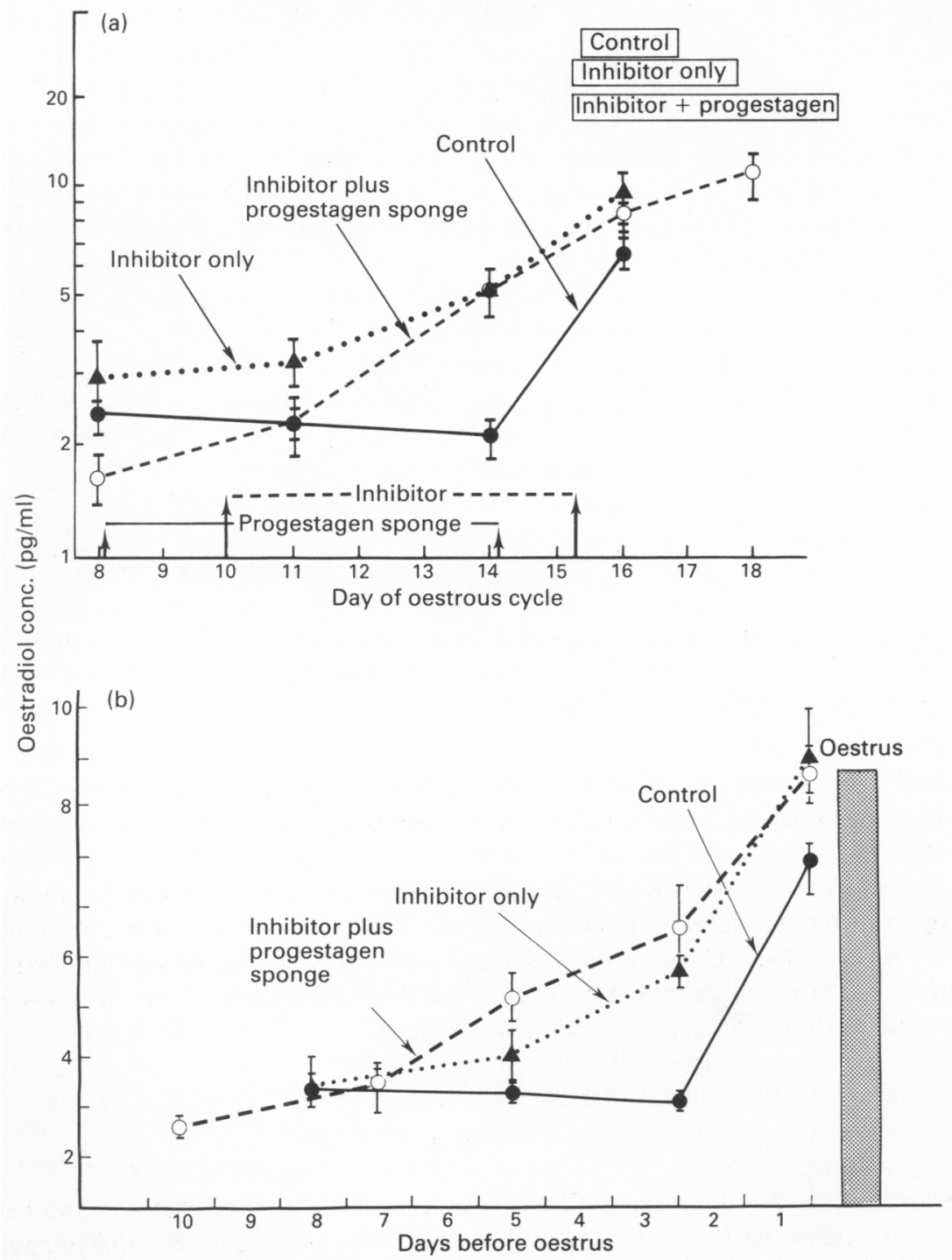

Fig. 3. Mean ( \pm s.e.m.) oestradiol concentrations during Exp. 1. (a) Data chronologically aligned in relation to the time of treatment. The range of oestrus for each group is indicated by the open bar containing the group treatment. (b) Data chronologically aligned in relation to the time of oestrous.

the ovaries. This is supported by the observation that, in Exp. 2 (Table 2), 2 ewes were anovulatory and a further 8 ewes failed to exhibit oestrus. As the ewes had been synchronized with a progestagen sponge treatment two oestrous cycles previously, the animals were perhaps not closely synchronized and the inhibitor was probably given later in the follicular phase. The inhibitor may therefore be interfering at the level of hypothalamus with the positive feedback effects of oestradiol, necessary to trigger both oestrous behaviour and the preovulatory gonadotrophin surge (see review by Baird $\&$ McNeilly, 1981). This conclusion is supported by the results from Exp. 1, indicating that peripheral oestradiol concentrations are not limiting and, in fact, were significantly increased by the treatment (Figs 3a \& 3b). A similar effect has been demonstrated after immunization against ovarian steroids 
(Fairclough et al., 1976; Scaramuzzi et al., 1981) when there is an optimum range of antibody titre (Webb et al., 1984); too high a titre led to abnormal follicular growth coupled with blocked oestrus and failure to ovulate. However, these effects of steroid antisera are probably caused by a lack of steroid feedback rather than by direct antibody action on the hypothalamus-pituitary gland.

One further possible cause of the increase in the number of ewes not showing oestrus, not ovulating and having cystic follicles in Exp. 2 may be due to the repeated treatment of the ewes. However, at the dose given the effect of the inhibitor on progesterone concentrations lasts for less than $24 \mathrm{~h}$ (Ashworth et al., 1987) and in Exp. 1, 2 ewes in the 3 $\beta$-HSD inhibitor only group (Table 1), not previously treated, also had cystic follicles. Furthermore, ewes not previously treated with the $3 \beta$-HSD inhibitor also showed cystic follicles and a few did not ovulate despite there being an overall increase in ovulation rate ( $R$. Webb, unpublished observation). Obviously, further studies are required to eliminate the possibility of any residual effect of repeated treatment with the $3 \beta-\mathrm{HSD}$ inhibitor.

Ovulation rate can be significantly reduced by oestradiol treatment (Webb \& Gauld, 1985a). By contrast, the increase in ovulation rate in these studies was associated with a significant increase in follicular oestradiol concentrations, despite a significant decrease in progesterone production by the corpus luteum. Steroid precursor for oestradiol production by the follicles is clearly not limiting, and the enhancement of circulating oestradiol concentrations may occur because there is increased passage of steroid precursors via the $\Delta^{5}$ enzyme pathway. Studies of women during the first trimester of pregnancy, with two different $3 \beta$-HSD inhibitors, have demonstrated an increase in pregnenolone and dehydroepiandrosterone concentrations (Van Der Spuy et al., 1983). The exact mechanism by which the effect on follicular growth and the increased ovulation rate is achieved is not known and further studies are currently in progress, but as discussed previously one possibility is that the treatment interferes with the hormonal feedback equilibrium between the hypothalamus-pituitary gland and the ovaries. A direct effect at the ovarian level cannot be discounted, however, especially as there was also an increase in peripheral oestradiol concentrations, follicular growth and ovulation in Group 3, which had been treated with inhibitor plus progestagen sponges.

The $3 \beta-H S D$ inhibitor significantly reduced peripheral progesterone concentration (Figs la \& 1b). After progestagen sponge treatment progesterone concentrations were significantly reduced even further and this was effective before the start of the inhibitor treatment. A similar observation, after progestagen treatment, has been noted in women (Johansson, 1971) and is due to a direct action of progestagen on the $3 \beta$-HSD enzyme system in the corpus luteum (Shinada et al., 1978). This can be overcome by gonadotrophin treatment (Johansson, 1971). Whether the effect is due to an additive action directly on the $3 \beta$-HSD enzyme system or via gonadotrophin secretion needs to be investigated.

One further observation was the increase in oestrous cycle duration in the ewes given the $3 \beta$-HSD inhibitor together with progestagen sponge treatment (Table 1; Figs la, $1 \mathrm{~b} \& 2$ ). This is probably due to a delay in the regression of the corpus luteum. The transient increase in peripheral progesterone concentrations in 3 of the ewes observed in Group 3 (Exp. 1) on Day 15 of the cycle (Fig. 1a) and particularly in Ewe 42 (Fig. 2), immediately after sponge withdrawal and the cessation of inhibitor treatment, suggests an effect on corpus luteum function rather than any residual effect from the progestagen sponge. Furthermore, no residual effect from progestagen sponge treatment was noted in the pretreatment synchronizationi cycle, during which oestrus occurred about $48 \mathrm{~h}$ after sponge removal, compared with the treatment cycle in which the interval from sponge removal to oestrus was at least 4 days.

The extension of the luteal phase is presumably not due to an increase in luteotrophic support, because the level of steroid negative feedback would have been maintained by the presence of the progestagen sponge together with the higher circulating values of oestradiol-17 $\beta$ (Figs $3 a \& 3 b$ ). One further possible explanation could be a lack of progesterone priming of the uterus thereby interfering with prostaglandin release and consequently luteolysis (Baird et al., 1976; Louis et al., 1977). However, a lack of progesterone priming as an explanation for the increased oestrous cycle 
length is doubtful as the ewes had been treated with progestagen sponges until Day 14. Furthermore, luteolysis appeared to occur normally in the ewes treated with inhibitor only (Fig. 1a \& 1 b) and the competitive inhibition of $3 \beta$-HSD activity is ineffective in bringing about structural luteolysis (Jenkin et al., 1984). It is possible that $3 \beta$-HSD enzyme activity plays a central role in the luteolytic mechanism and that the synergistic action of the inhibitor together with the synthetic progestagen perturbed this action.

Previous reports have demonstrated a close temporal association between peripheral progesterone and oxytocin concentrations (Webb et al., 1981; Sheldrick \& Flint, 1981), although Rice et al. (1986) have suggested that the release of progesterone from subcellular particles is not affected by treatments which stimulate the release of oxytocin from luteal granules. Oxytocin appears to be important for CL regression because immunization against oxytocin prolongs the luteal phase (Sheldrick et al., 1980; Schams et al., 1983). Furthermore, Flint \& Sheldrick (1985) have demonstrated that continuous infusion of oxytocin prevents luteal regression and delays the onset of behavioural oestrus in cyclic ewes, possibly by down regulating the uterine oxytocin receptor. If during luteolysis there is a positive feedback between oxytocin and endometrial PGF- $\alpha$ (Flint \& Sheldrick, 1982, 1983, 1985), then perturbation of this mechanism by the treatment given to ewes in Group 3 (Exp. 1) may have affected the timing of luteolysis.

In conclusion, these studies demonstrate that ovulation rate and production of lambs per ewe lambing can be significantly improved by $3 \beta$-HSD inhibitor treatment. Whether this approach will be of commercial significance depends on finding both a suitable dose to induce an increase in ovulation rate, without the detrimental side effects of blocking oestrus and ovulation, and also finding a simple delivery system.

I thank G. Baxter, J. Bracken, P. Davies, M. Fordyce, D. McBride, N. Sharp and B. Wilson for technical assistance; A. J. Springbett for carrying out the statistical analyses; W. Ritchie for artwork; J. Cherrie for typing the manuscript; W. E. Jones of Sterling-Winthrop for the Epostane ( $3 \beta$-HSD inhibitor); and J. E. T. Corrie for reagents for the progesterone assay.

\section{References}

Ashworth, C.J. (1985) Maternal factors affecting early pregnancy in sheep. Ph.D. thesis, Edinburgh University.

Ashworth, C.J., Wilmut, I., Springbett, A.J. \& Webb, R. (1987) The effect of an inhibitor of $3 \beta$-hydroxysteroid dehydrogenase on progesterone concentration and embryo survival in sheep. $J$. Endocr. (in press).

Baird, D.T. \& McNeilly, A.S. (1981) Gonadotrophin control of follicular development and function during the oestrous cycle of the ewe. J. Reprod. Fert., Suppl. 30, 119-133.

Baird, D.T., Land, R.B., Scaramuzzi, R.J. \& Wheeler, A.G. (1976) Endocrine changes associated with luteal regression in the ewe; the secretion of ovarian oestradiol, progesterone and androstenedione and uterine prostaglandin $\mathrm{F}_{2 a}$ throughout the oestrous cycle. $J$. Endocr. 69, 275-286.

Bindon, B.M. \& Piper, L.R. (1984) Endocrine basis of genetic difference in ovine prolificacy. Proc. $10 \mathrm{th}$ Int. Congr. Anim. Reprod. \& A.I., Urbana-Champaign, Vol. IV, Chapt. VI, pp. 17-26.

Black, J.L. (1983) Growth and development of lambs. In Sheep Production, pp. 21-55. Ed. W. Haresign. Butterworths, London.

Corrie, J.E.T., Hunter, W.M. \& Macpherson, J.S. (1981) A strategy for radioimmunoassay of plasma progester- one with the use of a homologous site ${ }^{125}$ I-labelled radioligand. Clin. Chem. 27, 594-599.

Dufour, J., Cahill, L.P. \& Mauleon, P. (1979) Short- and long-term effects on hypophysectomy and unilateral ovariectomy on ovarian follicular populations in sheep. J. Reprod. Fert. 57, 301-309.

Fairclough, R.J., Smith, J.F. \& Peterson, A.J. (1976) Passive immunization against oestradiol-17 $\beta$ and its effect on luteolysis, oestrus and ovulation in the ewe. J. Reprod. Fert. 48, 169-171.

Flint, A.P.F. \& Sheldrick, E.L. (1982) Ovarian secretion of oxytocin is stimulated by prostaglandin. Nature, Lond. 297, 587-588.

Flint, A.P.F. \& Sheldrick, E.L. (1983) Evidence for a systemic role for ovarian oxytocin in luteal regression in sheep. J. Reprod. Fert. 67, 215-225.

Flint, A.P.F. \& Sheldrick, E.L. (1985) Continuous infusion of oxytocin prevents induction of uterine oxytocin receptor and blocks luteal regression in cyclic ewes. J. Reprod. Fert. 75, 623-631.

Hanrahan, J.P. \& Quirke, J.F. (1985) Contribution of variation in ovulation rate and embryo survival to within breed variation in litter size. In Genetics of Reproduction in Sheep, pp. 193-201. Eds R. B. Land \& D. W. Robinson. Butterworths, London.

Hunter, R.H.F. (1980) Physiology and Technology of 
Reproduction in Female Domestic Animals. Academic Press, London.

Jenkin, G., Gemmell, R.T. \& Thorburn, G.D. (1984) Induction of transient functional luteolysis in cyclic sheep by a $3 \beta$-hydroxysteroid dehydroxgenase inhibitor. J. Endocr. 100,61-66.

Johansson, E.D.B. (1971) Depression of the progesterone levels in women treated with synthetic gestagens after ovulation. Acta endocr., Copenh. 68, 779-792.

Land, R.B. \& Carr, W.R. (1979) Reproduction in domestic mammals. In Genetic Variation in Hormone Systems, Vol. 1, pp. 89-112. Ed. J. G. M. Shire. C.R.C. Press, Florida.

Ledger, W.L., Webster, M.A., Anderson, D.B.M. \& Turnbull, A.C. (1985) Effect of inhibition of prostaglandin synthesis on cervical softening and uterine activity during ovine parturition resulting from progesterone withdrawal induced by epostane. $J$. Endocr. 105, 227-233.

Louis, T.M., Parry, D.M., Robinson, J.S., Thorburn, G.D. \& Challis, J.R.G. (1977) Effects of exogenous progesterone and oestradiol on prostaglandin $F_{2 a}$ and 13,14-dihydro-15-oxo prostaglandin $\mathrm{F}_{2 \alpha}$ concentrations in uteri and plasma of ovariectomized ewes. J. Endocr. 73, 427-439.

Martensz, N.D., Scarmuzzi, R.J. \& Van Look, P.F.A. (1979) Plasma concentrations of luteinizing hormone and follicle-stimulating hormone during anoestrus in ewes actively immunized against oestradiol-17 $\beta$, oestrone or testosterone. J. Endocr. 81, 261-269.

McNeilly, A.S., Jonassen, J.A. \& Fraser, H.M. (1986) Suppression of follicular development after chronic LHRH immunoneutralization in the ewe. $J$. Reprod. Fert. 76, 481-490.

Pathiraja, N., Carr, W.R., Fordyce, M., Forster, J., Land, R.B. \& Morris, B.A. (1984) Concentration of gonadotrophins in the plasma of sheep given gonadal steroid antisera to raise ovulation rate. J. Reprod. Fert. 72, 93-100.

Pattison, N.S., Webster, M.A., Phipps, S.L., Anderson, A.B.M. \& Gillmer, M.D.G. (1984a) Prolonged inhibition of placental and ovarian $3 \beta$-hydroxysteroid dehydrogenase during pregnancy and the luteal phase of the menstrual cycle. J. Obstet. Gynaec. 5, $69-74$.

Pattison, N.S., Webster, M.A., Phipps, S.L., Anderson, A.B.M. \& Gillmer, M.D.G. (1984b) Inhibition of $3 \beta$-hydroxysteroid dehydrogenase (HSD) activity in first- and second-trimester human pregnancy and luteal phase using Epostane. Fert. Steril. 42, 875-881.

Rice, G.E., Jenkin, G. \& Thorburn, G.D. (1986) Comparison of particle-associated progesterone and oxytocin in the ovine corpus luteum. J. Endocr. 108, $109-116$.

Rodbard, D. \& Lewald. J.G. (1970) Computer analysis of radioligand assay and radioimmunoassay data. Acta. endocr., Copenh., Suppl. 147, 79-103.

Scaramuzzi, R.J. \& Hoskinson, R.M. (1984) Immunoneutralization of steroid hormones for increasing fecundity. In Immunological Aspects of Reproduction, pp. 445-474. Ed. D. B. Crighton. Butterworths, London.

Scaramuzzi, R.J., Baird, D.T., Martensz, N.D., Turnbull, K.E. \& Van Look, P.F.A. (1981) Ovarian function in the ewe after active immunization against testosterone. J. Reprod. Fert. 61, 1-9.
Schams, D., Prokopp, S. \& Barth, D. (1983) The effect of active and passive immunization against oxytocin on ovarian cyclicity in ewes. Acta endocr., Copenh. 103, $337-344$.

Schane, H.P., Potts, G.O. \& Creange, J.E. (1979) Inhibition of ovarian, placental and adrenal steroidogenesis in the rhesus monkey by trilostane. Fert. Steril. 32, $464-467$.

Scheffe, H. (1959) The Analysis of Variance. Wiley, New York.

Sheldrick, E.L. \& Flint, A.P.F. (1981) Circulating concentrations of oxytocin during the estrous cycle and early pregnancy in sheep. Prostaglandins 22, 631-636.

Sheldrick, E.L., Mitchell, M.D. \& Flint, A.P.F. (1980) Delayed luteal regression in ewes immunized against oxytocin. J. Reprod. Fert. 59, 37-42.

Shinada, T., Yokota, Y. \& Igarashi, M. (1978) Inhibitory effect of various gestogens upon the progesterone $3 \beta$ ol-dehydrogenase- $\Delta 5$-4-isomerase system in human corpora lutea or menstrual cycles. Fert. Steril. 29, 84-87.

Snyder, B.W., Beecham, G.D. \& Schane, H.P. (1984) Inhibition of ovulation in rats with Epostane, an inhibitor of 3 $\beta$-hydroxysteroid dehydrogenase. Proc. Soc. exp. Biol. Med. 176, 238-242.

Taylor, M.S., Webb, R., Mitchell, M.D. \& Robinson, J.S. (1982) Effect of progesterone withdrawal in sheep during late pregnancy. $J$. Endocr. 92, 185-193.

Van Der Spuy, Z.M., Jones, D.L., Wright, C.S.W., Puira, B., Paintin, D.B., James, V.H.T. \& Jacobs, H.S. (1983) Inhibition of 3-beta-hydroxysteroid dehydrogenase activity in first trimester human pregnancy with Trilostane and WIN 32729. Clin. Endocr. 19, 521-532.

Webb, R. \& Gauld, I.K. (1985a) Folliculogenesis in sheep: control of ovulation rate. In Genetics of Reproduction in Sheep, pp. 261-274. Eds R. B. Land \& D. W. Robinson. Butterworths, London.

Webb, R. \& Gauld, I.K. (1985b) Genetics and physiology of follicle recruitment and maturation during seasonal anoestrus. In Endocrine Causes of Seasonal and Lactational Anoestrus in Farm Animals, pp. 19-28. Eds F. Ellendorff \& F. Elsaesser. Martinus Nijhoff, Dordecht.

Webb, R. \& Gauld, I.K. (1986) Endocrine control of follicular growth in the ewe. In Follicular Growth and Ovulation Rate in Farm Animals. Eds. J. F. Roche \& D. O. Callaghan. Martinus Nijhoff, Dordecht (in press).

Webb, R., Mitchell, M.D., Falconer, J. \& Robinson, J.S. (1981) Temporal relationships between peripheral plasma concentrations of oxytocin, progesterone and 13,14-dihydro-15-keto-prostaglandin $F_{2 a}$ during the oestrous cycle and early pregnancy in the ewe. Prostglandins 22, 443-454

Webb, R., Land, R.B., Pathiraja, N. \& Morris, B.A. (1984) Passive immunization against steroid hormones in the female. In Immunological Aspects of Reproduction, pp. 475-499. Ed. D. B. Crighton. Butterworths, London.

Webb, R., Baxter, G., McBride, D., Nordblom, G.D. \& Shaw, M.P.K. (1985) The measurement of testosterone and oestradiol- $17 \beta$ using iodinated tracers and incorporating an affinity chromatography extraction procedure. J. Steroid Biochem. 23, 1043-1051. 